\title{
Integrated optical components based on planar photonic crystal waveguides with perturbed border holes
}

Niemi, Tapio; Frandsen, Lars Hagedorn; Harpøth, Anders; Borel, Peter Ingo; Kristensen, Martin

Published in:

Conference on Lasers and Electro-Optics Europe, 2005. CLEO/Europe.

Link to article, DOI:

10.1109/CLEOE.2005.1568365

Publication date:

2005

Document Version

Publisher's PDF, also known as Version of record

Link back to DTU Orbit

Citation $(A P A)$ :

Niemi, T., Frandsen, L. H., Harpøth, A., Borel, P. I., \& Kristensen, M. (2005). Integrated optical components based on planar photonic crystal waveguides with perturbed border holes. In Conference on Lasers and ElectroOptics Europe, 2005. CLEO/Europe. IEEE. https://doi.org/10.1109/CLEOE.2005.1568365

\section{General rights}

Copyright and moral rights for the publications made accessible in the public portal are retained by the authors and/or other copyright owners and it is a condition of accessing publications that users recognise and abide by the legal requirements associated with these rights.

- Users may download and print one copy of any publication from the public portal for the purpose of private study or research.

- You may not further distribute the material or use it for any profit-making activity or commercial gain

- You may freely distribute the URL identifying the publication in the public portal 


\title{
Integrated optical components based on planar photonic crystal waveguides with perturbed border holes
}

\author{
Tapio Niemi \\ Research Center COM, Technical University of Denmark, Building 345v, DK-2800, Kgs. Lyngby, Denmark. \\ Present address: Optoelecronics Research Center, Tampere University of Technology, P.O. Box 692, \\ FIN-33101 Tampere, Finland, Tapio.Niemi@orc.tut.fi. \\ Lars Hagedorn Frandsen, Anders Harpфth, and Peter Ingo Borel \\ Research Center COM, Technical University of Denmark, Building 345v, DK-2800, Kgs. Lyngby, Denmark.

\section{Martin Kristensen} \\ Research Center COM, Technical University of Denmark, Building 345v, DK-2800, Kgs. Lyngby, Denmark. \\ Present address: Department of Physics and Astronomy, Aarhus University, DK-8000, Aarhus C, Denmark.
}

Photonic crystal structures fabricated in planar semiconductor materials open possibilities for an ultra-high packaging density of integrated optics. In planar photonic crystals light is vertically confined by total internal reflection and horizontally by an in-plane bandgap resulting from a periodic pattern of air holes. Waveguiding through sharp bends, novel dispersion properties, and extremely small cavities can be realized using these structures.

In this work, we have experimentally and by simulations investigated the effect of making small perturbations of the size of the border holes adjacent to the planar photonic crystal waveguide (PCW). The waveguide is created by removing one row of holes in the nearest-neighbour direction of air holes placed on a triangular lattice with pitch $\Lambda=380 \mathrm{~nm}$ in a silicon-on-insulator (SOI) material. Changes in the diameter of the border holes lead to large shifts in the cut-off of the fundamental photonic bandgap (PBG) mode and its dispersion properties [1,2]. We have fabricated and characterised examples of various components utilising the novel characteristics of the border hole-modified waveguides. The patterns defining the components were written with electron-beam lithography on a resist, which was spun on a SOI-wafer. The patterns on the resist were transferred to the top silicon layer by reactive ion-etching.
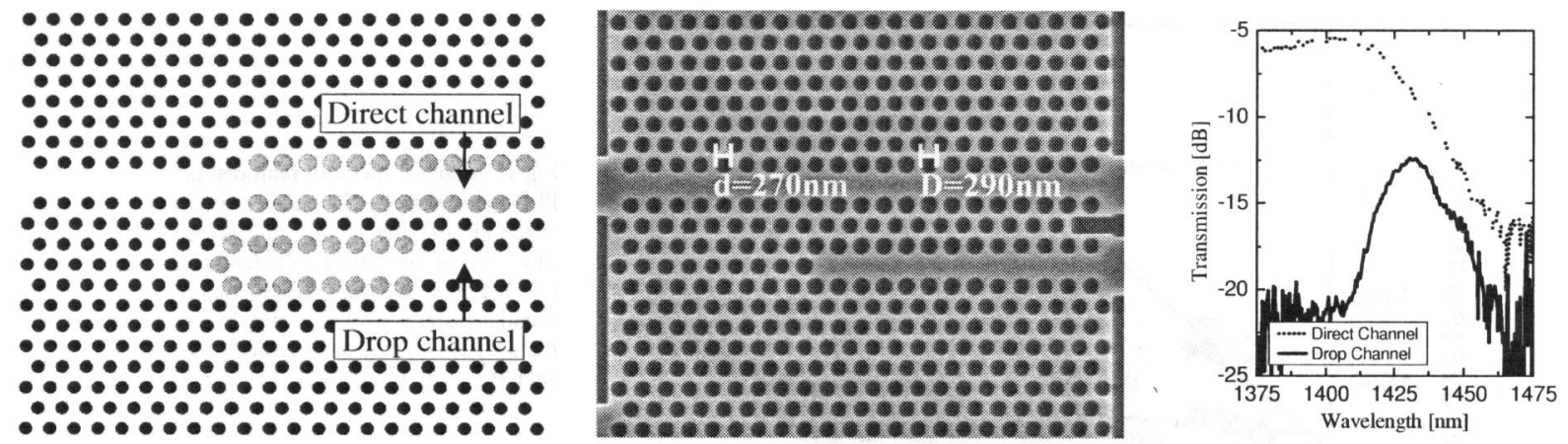

The figure above shows the design (left) and a scanning electron micrograph (middle) of a wavelength selective directional coupler based on perturbed border holes. This component is designed to split and couple a narrow wavelength band. The wavelength selective operation is achieved by enlarging the size of the border holes (indicated as grey holes in the left figure) of the waveguides in the coupling region, which has a length of only $7 \Lambda$. Enlarged border holes shift the cut-off of the PBG mode to shorter wavelengths. Therefore, the transmission of longer wavelengths will be blocked in the direct channel and the light couples to the drop channel. The operation characteristics can be tuned by changing the coupling length and the diameter of the holes. The graph shows the measured transmission for TE-like polarised light in the direct and drop channels. The spectra are normalised to the transmission through a PCW of similar length. The drop channel is located near the cut-off of the PBG mode as designed. Optimization of the structural parameters and fabrication tolerances are needed to improve the loss of the component. The size of this new coupler is only $\sim 8 \mu \mathrm{m} \times 7 \mu \mathrm{m}$ and the operational bandwidth is suitable for coarse wavelength division multiplexing in optical communications.

References:

[1] A. Adibi, R. K. Lee, Y. Xu, A. Yariv and A. Scherer, "Design of photonic crystal optical waveguides with singlemode propagation in the photonic bandgap," Electron. Lett., Vol. 36, pp. 1376-1378, 2000.

[2] M. Notomi, A. Shinya, S. Mitsugi, E. Kuramochi, and H. -Y. Ryu, "Waveguides, resonators and their coupled elements in photonic crystal slabs, ” Opt. Express, Vol. 12, pp. 1551-1561, 2004. 